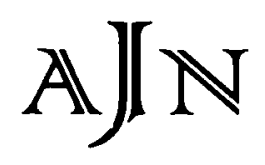

Original Article

\title{
Role of serum tumour necrosis factor alpha and its soluble receptors in predicting acute renal allograft rejection
}

\author{
Seham Ahmed Said *, Mostafa Ayman Mahmoud ** and Ibrahim Abu El-Fettouh \\ Laboratory *, Nephrology department **, National Institute of Urology \& Nephrology, Egypt
}

\begin{abstract}
Tumour necosis factor alpha (TNF- $\alpha$ ) is known to be involved in pathogenesis of acute renal allograft rejection. However, measurement of cytokine serum levels alone are not a reliable index of acute rejection episodes. TNF- $\alpha$ induces the release of soluble receptors (TNF-SR55 and TNF-SR75) that have an inhibitory activity and catabolized by the kidney.

Twenty nine transplant recepients were studied and compared to ten healthy controls. TNF- $\alpha$, TNF-SR55 and TNF-SR75 were measured before and after renal transplantation. The mean pre-transplantation values were $26.3 \pm 9.7 \mathrm{pg} / \mathrm{ml}, 28.2 \pm 8.3$ and $42.5 \pm 11.1$ $\mathrm{ng} / \mathrm{ml}$ respectively. According to post-transplant course patients were divided into 3 groups. Group I (stable transplant group: $\mathrm{no}=17$ ): The mean level of TNF- $\alpha$ value was $7.5 \pm 4.6 \mathrm{pg} / \mathrm{ml}$, TNF-SR55 $6.4 \pm$ 4.7 and TNF-SR75 $12.5 \pm 8 \mathrm{ng} / \mathrm{ml}$ (p NS). Group II (acute allograft rcjection group: no $=8$ ): The mean values were $37.2 \pm 16.2 \mathrm{pg} / \mathrm{ml}, 16.9 \pm 9.6$ and $30.9 \pm$ $13.4 \mathrm{ng} / \mathrm{ml}$ respectivcly $(\mathrm{p}<0.05)$. Group III cyclosporine $(C S)$ nephroloxicity group: no $=4$ ): The mean level of TNF- $\alpha$ was $9.9 \pm 2.1 \mathrm{pg} / \mathrm{ml}$ with a highly significant increase in its receptor values $(9.4 \pm 1.0 \&$ $21.2 \pm 6.8 \mathrm{ng} / \mathrm{ml} ;$ vs $5.5 \pm 1.2 \& 12.4 \pm 4.8 \mathrm{ng} / \mathrm{ml}$ respectively $(\mathrm{P}<0.01)$.

To improve the predictive value of this cytokine and its receptors, we calculated the ratios of TNF- $\alpha$ to both receptors (SR55-SR75).

During acute rejection episode, the ratio values to control were $2.4 \pm 0.6$ vs $1.4 \pm 0.7$ and $1.3 \pm 0.5$ vs $0.7 \pm 0.4$ respectively $(\mathrm{P}<0.01)$.
\end{abstract}

Correspondence and offprim requesis to: Seham Ahmed Said, Laboratory Department, National Institute of Nephrology \& Urology, 4 EL-Horeya Strcel, Matareya, Cairo, Egypt.
However, these ratios did not change significantly from control group during CS nephrotoxicity $1.5 \pm$ 0.5 vs $2.0 \pm 0.7$ and $0.5 \pm 0.3$ vs $0.9 \pm 0.2$ respectively ( $p>0.05$ ). Thus, TNF- $\alpha$ and its soluble receptor levels might be of diagnostic value in renal allograft rejecion.

In conclusion: 1) TNF- $\alpha$ and its soluble receptors are highly increased during hemodialysis. 2) There is no significant difference between healthy controls and patients with stable grafts. 3)There is highly significant increase of TNF- $\alpha$ and its receptors during acute rejection episodes and the day (R-2) prerejection in contrast to internal controls. 4) There is insignificant decrease of TNF- $\alpha$ during CS nephrotoxicity with highly significant increase of TNF-SR55, TNF-SR75 when compared to internal controls. 5) The ratios of TNF- $\alpha$ to SR55 \& SR75 showed highly significant increase during acute rejection episodes and insignifi-cant decrease during CS nephroloxicity when compared to internal controls.

Key words: acute allograft rejection; cyclosporine nephrotoxicity; renal transplantation; tumour necrosis factor

\section{Introduction}

Allograft biopsy remains the standard method for diagnosis of acute rejection. However, this proceedure always carries a risk. Thus it might be of great value to have a non-invasive diagnostic modality. Cytokines released early in immune cell activation appear promising in this respect $[7,15]$. 
The macrophage cytokine tumour necrosis factor alpha (TNF- $\alpha$ ) is released in relatively large amounts early during immune activation process [13] and is readily detected in the circulation $[4,14]$. It expresses its biological activity by triggering specific receptors on a variety of different cells including monocytes, lymphocytes, endothelial cells, fibroblasts and mesangial cells $[8,10]$. Therefore, it may be an early marker of immune activation.

Two cellular TNF receptors have been specified. Brockhaus (1990) and Dembic (1990), defined them as soluble TNF receptors, namely $55 \mathrm{KDa}$ (TNFSR55) and $75 \mathrm{KDa}$ (TNF-SR75). Their plasma halflife is longer than that of TNF- $\alpha$. It is easier to measure these soluble receptors in serum and may constitute a more reliable parameter than TNF- $\alpha$ itself [7].

In this study, we evaluated the reliability of serum levels of TNFa and its soluble receptors in detecting renal allograft rejection.

\section{Materials and methods}

\section{Patients}

This study included 29 patients (21 males and 8 females) with mean age 34.1 years (range: 19-51 years). All had end stage renal disease and were on regular haemodialysis treatment for a mean duration of 18.4 months (range: 3-72 months). Aetiologicaly, end stage renal disease (ESRD) was due to: chronic glomerulonephritis in 21 , polycystic kidney disease in 3 and bilateral multiple renal stones in 5 patients. All recipients had their first successful living renal transplantation $(T x)$ at the National Institute of Urology and Nephrology during the period from January, 1995- April, 1997. Patients with intercurrent infections or with known chronic inflammatory diseases were excluded. The immunosuppressive regimen was either imuran and prednisolone in 17 or imuran, cyclosporine A (CSA) and prednisolone in 12 patients (Table 1).

\section{Controls}

This group included ten healthy individuals ( 7 males and 3 females) of comparable age.

\section{Blood collection and techniques}

- Blood samples were taken one day before transplantation (day-1) and daily during the period of post-operative hospitalization (day $+1,+2$, etc.).

- Sera were stored at $-70^{\circ} \mathrm{C}$ for cytokine assay.

- Concomitantly, estimation of serum creatinine (every day) and whole CSA levels (every third day) were done.
- TNF- $\alpha$ and its soluble receptors were measured by enzyme linked immunosorbent assay (ELISAMedgenix Diagnostics S.A., Fleurus, Belgium) in sera collected on the following days:

1. Sera of all patients (no.29) were analysed the day before Tx (day-1).

2. Group I (patients with stable graft function: no= 17): samples were analysed at day +15 .

3. Group II (patients with acute allograft rejection: no=8) samples were analysed at days of stable graft function (internal controls), 2 days pre-rejection (R-2) and at the peak of acute rejection episode (R0).

4. Group III (patients with cyclosporine nephrotoxicity: no=4): Sera were analysed at days of stable graft function (internal controls) and when CSA nephrotoxicity was diagnosed.

\section{Statistical analysis}

Statistical analysis was performed using student's-t test for the independent groups and paired-t test for matched groups. The level of significance was set at $\mathrm{p}$ value $<0.05$. All values were expressed as means \pm standard deviation.

\section{Results}

According to the post-operative course, patients were divided into three groups (Table 1):

\section{Group I. Stable transplant group}

Comprised 17 patients ( 12 males and 5 remales) of mean age 34.1 years. There was no acute rejection episodes or CS-A nephrotoxicity during the period of the study (one month postoperative). The mean serum creatinine was $1.3 \mathrm{mg} / \mathrm{dl}$.

\section{Group II. Acute allograft rejection group}

Comprised 8 patients ( 5 males and 3 females) of mean age 33.9 years. These patients had at least one acute rejection episode. Their mean serum creatinine value was $4.0 \mathrm{mg} / \mathrm{dl}$ during the episode.

\section{Group III. Cyclosporin nephrotoxicity group}

Comprisud 4 male patients, of mean age 36.0 years. Cyclosporine nephrotoxicity was defined as progressive deterioration of renal function associated with high blood level of CSA in absence of any other cause e.g. obstruction or rejection and which improved after reduction of CSA dose.

Renal allograft recipients were monitored before and during posttransplant peroid (Figure 1 and 2): 
Table 1. Patients' characteristics

\begin{tabular}{|c|c|c|c|c|c|c|c|c|}
\hline & \multirow{2}{*}{$\begin{array}{l}\text { Number of } \\
\text { patients }\end{array}$} & \multirow{2}{*}{ Age (vears) } & \multicolumn{2}{|c|}{$\operatorname{Sex}$} & \multirow{2}{*}{$\begin{array}{l}\text { Duration of dialysis } \\
\text { (months) }\end{array}$} & \multicolumn{3}{|c|}{ Immumo-suppression } \\
\hline & & & Male & Female & & Imuran + pred & $\begin{array}{l}\text { Imuran } \\
\text { pred. } \\
+ \text { CS A } \\
\end{array}$ & + \\
\hline Total & 29 & $2 \pm 8$ & 21 & 8 & $7 \pm 15$ & 17 & 12 & \\
\hline Group I & 17 & $9 \pm 7$ & 12 & 5 & $16.1 \pm 8.9$ & 11 & 6 & \\
\hline Group II & 8 & $3 \pm 9$ & 5 & 3 & $5 \pm 17$ & 6 & 2 & \\
\hline Group III & 4 & $36 \pm 11.3$ & 4 & - & $7 \pm 29$ & - & 4 & \\
\hline
\end{tabular}

Fig. 1. Means \pm S.D of serum TNF - $\alpha$ in different groups

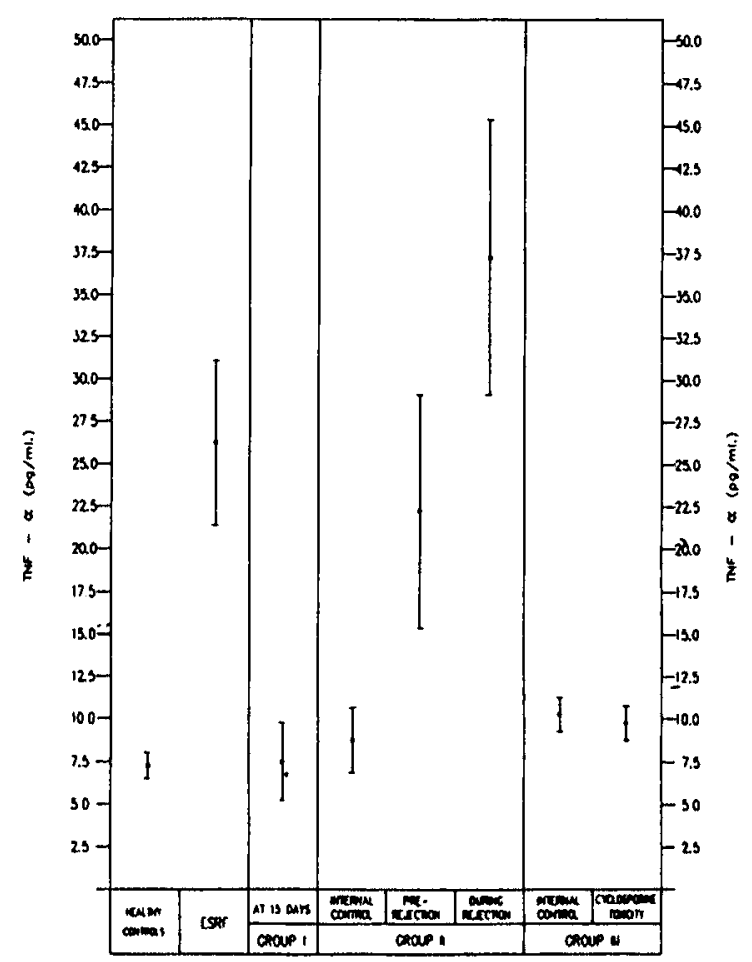

1. Serum TNF- $\alpha$ and its soluble receptors in healthy controls and group I:

Values were $7.3 \pm 1.6$ vs $7.5 \pm 4.6 \mathrm{pg} / \mathrm{ml}$ for TNF$\alpha, 5.9 \pm 2.2 \mathrm{Vs} 6.4 \pm 4.7 \mathrm{ng} / \mathrm{ml}$ for TNF-SR55 and $8.9 \pm 3.0 \mathrm{Vs} 12.5 \pm 8.0 \mathrm{ng} / \mathrm{ml}$ for TNF-SR75 respectively $(\mathrm{P}>0.05)$.

Both groups showed insignificant difference in the levels of TNF- $\alpha$, SR55 and SR75 (Table 2).
Fig. 2. Means \pm S.D of serum TNF-SR55 \& TNF-SR75 in different groups

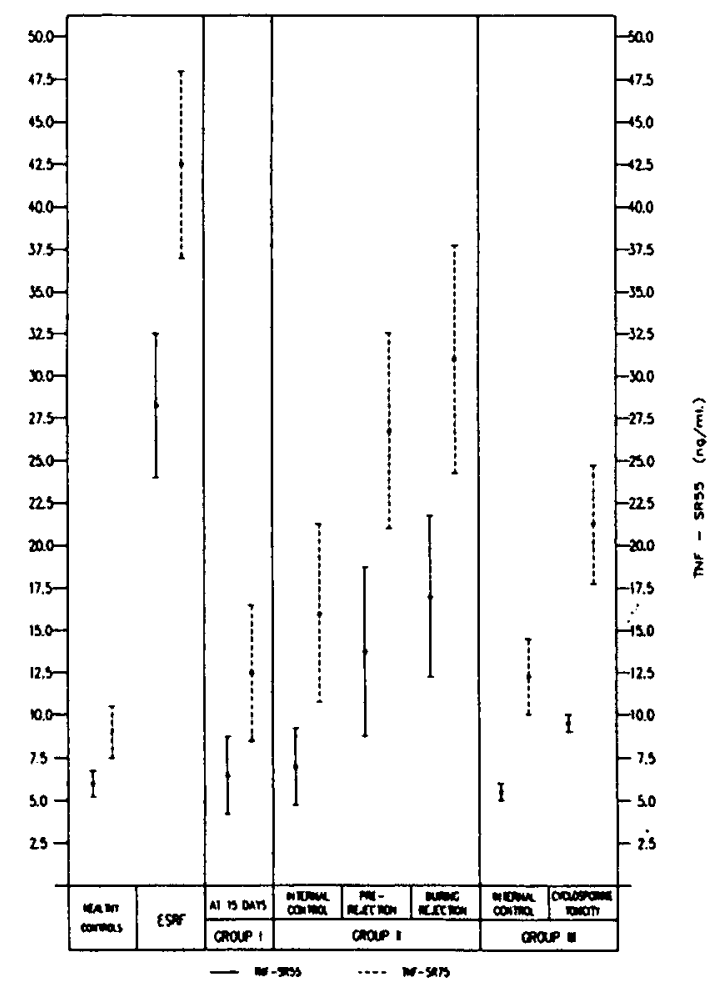

2. Serum TNF- $\alpha$ and its soluble receptors in ESRD:

In contrast to controls and group I, patients with ESRD had elevated levels. TNF- $\alpha(26.3 \pm 9.7)$ ranged from 13.5 to $48.3 \mathrm{pg} / \mathrm{ml}$, SR55 (28.2 \pm 8.3) ranged from 12.4 to $45.1 \mathrm{ng} / \mathrm{ml}$ while SR75 $(42.5 \pm 11.1)$ ranged from 23.3 to $55.9 \mathrm{ng} / \mathrm{ml}$ (Table 2). 
Table 2. Serum values of TNF- $\alpha$ and its soluble receptors in healthy controls, end stage renal failure (Pre-Tx) and in group I (day +15 following $\mathrm{Tx}$.)

\begin{tabular}{|c|c|c|c|c|c|}
\hline & \multirow{2}{*}{ Healthy controls (No. 10) } & \multicolumn{2}{|c|}{ During haemodialysis (Pre-Tx) (No. 29) } & \multicolumn{2}{|c|}{ Group I (No. 17} \\
\hline & & Pre-Tx (Day-1) & P. value & $\begin{array}{l}\text { Day }+15 \\
\text { post-Tx }\end{array}$ & P. value \\
\hline TNF- $\alpha(\mathrm{pg} / \mathrm{ml})$ & $7.3 \pm 1.6$ & $26.3 \pm 9.7$ & $\begin{array}{l}<0.01 \\
\text { (H.S.)* }\end{array}$ & $7.5 \pm 4.6$ & $\begin{array}{l}<0.05 \\
\text { (N.S.) }\end{array}$ \\
\hline $\begin{array}{l}\text { TNF-SR55 } \\
(\mathrm{ng} / \mathrm{ml})\end{array}$ & $5.9 \pm 2.2$ & $28.2 \pm 8.3$ & $\begin{array}{l}<0.01 \\
(\text { H.S. })\end{array}$ & $6.4 \pm 4.7$ & $\begin{array}{l}>0.05 \\
\text { (N.S.) }\end{array}$ \\
\hline $\begin{array}{l}\text { TNF-SR75 } \\
\text { (ng/ml) }\end{array}$ & $8.9 \pm 3.0$ & $42.5 \pm 11.1$ & $\begin{array}{l}>0.01 \\
\text { (H.S.) }\end{array}$ & $12.5 \pm 8.0$ & $\begin{array}{l}>0.05 \\
\text { (N.S.) }\end{array}$ \\
\hline
\end{tabular}

HS $=$ Highly significant *

3. Serum TNF- $\alpha$ and its soluble receptors in group II:

In comparison to internal controls (during stable allograft function), there was highly significant increase of TNF- $\alpha$ and its solube receptors during acute rejection episode: TNF- $\alpha(8.8 \pm 3.8$ Vs 37.2 $\pm 16.2 \mathrm{pg} / \mathrm{ml})$, SR55 $(7.0 \pm 4.3$ Vs $16.9 \pm 9.6$ $\mathrm{ng} / \mathrm{ml})$ and SR75 $(16.1 \pm 10.3$ Vs $30.9 \pm 13.4$ $\mathrm{ng} / \mathrm{ml})(\mathrm{P}<0.01)$. A significant increase in levels of TNF- $\alpha$ and soluble receptors was observed on comparing values of internal controls to those of the day R-2 $(22.4 \pm 13.7 \mathrm{pg} / \mathrm{ml}, 13.8 \pm 10.1 \&$ $26.8 \pm 11.6 \mathrm{ng} / \mathrm{ml}$ respectively $\mathrm{P}<0.05$ ) (Table $3)$.

Table 3. Serum values of TNF- $\alpha$ and its soluble receptors in group II.

\begin{tabular}{|c|c|c|c|c|c|}
\hline & \multirow{2}{*}{$\begin{array}{l}\text { Stable function (internal } \\
\text { controls) }\end{array}$} & \multicolumn{2}{|c|}{ Pre-rejection } & \multicolumn{2}{|c|}{ During rejecrion } \\
\hline . & & R-2 & P. value & Ro & P. value \\
\hline $\mathrm{TNF}-\alpha(\mathrm{pg} / \mathrm{ml})$ & $8.8 \pm 3.8$ & $22.4 \pm 13.7$ & $P<0.05$ & $37.2 \pm 16.2$ & $\begin{array}{l}P<0.01 \\
(\text { (II.S.)* }\end{array}$ \\
\hline $\begin{array}{l}\text { TNF-SR55 } \\
\text { (ng/ml) }\end{array}$ & $7.0 \pm 4.3$ & $13.8 \pm 10.1$ & $P<0.05$ & $16.9 \pm 9.6$ & $\begin{array}{l}\mathrm{P}>0.01 \\
\text { (H.S.) }\end{array}$ \\
\hline $\begin{array}{l}\text { TNF-SR75 } \\
(\mathrm{ng} / \mathrm{ml})\end{array}$ & $16.1 \pm 10.3$ & $26.8 \pm 11.6$ & $P>0.05$ & $30.9 \pm 13.4$ & $\begin{array}{l}P>0.01 \\
\text { (II.S.) }\end{array}$ \\
\hline
\end{tabular}

HS = Highly significant *

4. Serum TNF- $\alpha$ and its soluble receptors in group III:

Compared to internal controls obtained during clinically stable course in group III (Table 4), there was insignificant decrease $(P>0.05)$ in the levels of TNF- $\alpha$ during CSA nephrotoxicity (10.3 $\pm 1.9 \mathrm{Vs} 9.9 \pm 2.1 \mathrm{pg} / \mathrm{ml}$ ) with highly significant increases of SR55 and SR75 levels $(5.5 \pm 2.1 \mathrm{Vs}$ $9.4 \pm 1.0$ and $12.4+4.8 \mathrm{Vs} 21.2 \pm 6.8 \mathrm{ng} / \mathrm{ml}$ respectively) $(P<0.01)$

Table 4. Levels of TNF- $\alpha$ and its soluble receptors in CSA nephrotoxicity group.

\begin{tabular}{|c|c|c|c|}
\hline & $\begin{array}{l}\text { Stable function (internal } \\
\text { controls) }\end{array}$ & During CS-A nephroloxicity & Pvalue \\
\hline $\mathrm{TNF}-\alpha(\mathrm{pg} / \mathrm{m} 1)$ & $10.3 \pm 1.9$ & $9.9 \pm 2.1$ & $\begin{array}{l}\mathrm{P}<0.05 \\
(\text { N.S. })^{* *}\end{array}$ \\
\hline $\begin{array}{l}\text { TNF-SR55 } \\
(\mathrm{ng} / \mathrm{ml})\end{array}$ & $5.5 \pm 1.2$ & $9.4 \pm 1.0$ & $\begin{array}{l}\mathrm{P}>0.01 \\
(\text { H.S. })^{*}\end{array}$ \\
\hline $\begin{array}{l}\text { TNF-SR75 } \\
(\mathrm{ng} / \mathrm{ml})\end{array}$ & $12.4 \pm 4.8$ & $21.2 \pm 6.8$ & $\begin{array}{l}P>0.01 \\
(\text { II.S. })^{*}\end{array}$ \\
\hline
\end{tabular}

HS = Highly significant *, NS = Insignificant ** 
5. Changes in the ratio of circulating TNF- $\alpha$ over its receptors levels during renal allograft rejection and CS-A nephrotoxicily (Table 5):

On calculating the ratios it was observed that both ratios were significantly increased during acute rejection episodes when compared to internal controls $(2.4 \pm 0.6 \mathrm{Vs} 1.4 \pm 0.7$ and $1.3 \pm 0.5 \mathrm{Vs}$ $0.7 \pm 0.4 ; \mathrm{P}<0.01)$ and decreased insignificantly during CSA nephrotoxicity in contrast to internal controls $(1.5 \pm 0.5 \mathrm{Vs} 2.0 \pm 0.7$ and $0.5 \pm 0.3 \mathrm{Vs}$ $0.9 \pm 0.2 ; \mathrm{P}>0.01)$.

Table 5. Ratios of TNF- $\alpha$ and soluble TNF receptors

\begin{tabular}{|c|c|c|c|c|c|c|c|c|}
\hline & \multirow{2}{*}{$\begin{array}{l}\text { Stable graft group } \\
\text { (group I) }\end{array}$} & \multicolumn{4}{|c|}{$\begin{array}{l}\text { Acute rejection group } \\
\text { (group II) }\end{array}$} & \multicolumn{3}{|c|}{$\begin{array}{l}\text { CS-nephrotoxicity group } \\
\text { (group III) }\end{array}$} \\
\hline & & $\begin{array}{l}\text { Internal } \\
\text { controls }\end{array}$ & $\mathrm{R}-2$ & $\mathrm{R} 0$ & $\begin{array}{l}P \\
\text { value }\end{array}$ & $\begin{array}{l}\text { Internal } \\
\text { controls }\end{array}$ & CS-toxicity & $P$ value \\
\hline $\begin{array}{l}\text { TNF- } \alpha / \text { SR } 55 \\
D \text { range }\end{array}$ & $\begin{array}{l}1.5 \pm 1.0 \\
(0.5-3.8)\end{array}$ & $\begin{array}{l}1.4 \pm 0.7 \\
(0.7-2.1)\end{array}$ & $\begin{array}{l}1.8 \pm 0.6 \\
(0.7-2.7)\end{array}$ & $\begin{array}{l} \pm 0.6 \\
(1.1-3.4)\end{array}$ & $\begin{array}{l}<0.01 \\
\text { (H.S.) } \\
*\end{array}$ & $\begin{array}{l}2.0 \pm 0.7 \\
(1.2-2.7)\end{array}$ & $\begin{array}{l}1.5 \pm 0.5 \\
(0.8-1.3)\end{array}$ & $\begin{array}{l}>0.05 \\
(\text { N.S. })^{* *}\end{array}$ \\
\hline $\begin{array}{l}\text { TNF- } \alpha / \text { SR75 } \\
D \text { range }\end{array}$ & $\begin{array}{l}0.7 \pm 0.5 \\
(0.3-1.3)\end{array}$ & $\begin{array}{l}0.7 \pm 0.4 \\
(0.2-1.5)\end{array}$ & $\begin{array}{l}0.8 \pm 0.3 \\
(0.2-1.2)\end{array}$ & $\begin{array}{l} \pm 0.5 \\
(0.6-2.2)\end{array}$ & $\begin{array}{l}<0.01 \\
(\mathrm{H} . \mathrm{S} .) \\
*\end{array}$ & $\begin{array}{l}0.9 \pm 0.2 \\
(0.5-1.5)\end{array}$ & $\begin{array}{l}0.5 \pm 0.3 \\
(0.3-0.8)\end{array}$ & $\begin{array}{l}>0.05 \\
(\text { N.S. })^{* *}\end{array}$ \\
\hline
\end{tabular}

HS = llighly significant $*$, NS = Insignificant **

\section{Discussion}

Renal allograft rejection involves several cylokines which are produced by infiltrating $\mathrm{T}$ lymphocytes and macrophages. TNF- $\alpha$ is responsible for the inflammatory process as well as the local and systemic manifestations during rejection. It also has cytolytic aclivity and ability to stimulate immune competent cells to produce interleukin-1. The latter leads to an enhanced interleukin-2 production by $T$ cells [14]. TNF- $\alpha$ is an extremely pluripotent cytokine involved in various immunological events $[1,16]$. It destroys the graft tissue either directly or indirectly through the relcase of other cylokines.

Two cellular $\mathrm{TNF}$ receptors have been clearly distinguished: TNF-SR55 and TNF-SR75 [2,5]. If TNF- $\alpha$ concentration increases, the surface receptors will be upregulated. Consequently many of these surface receptors will loose their binding sites by shedding the extracellular domain to body fluids such as plasma, probably through proteolytic cleavage. This released part is defined as soluble TNF receptor [12]. These soluble molecules in plasma are capable of binding TNF with high affinity and specificity [19]. Thus acting as a physiological immunoregulatory mechanism for protecting the host against the deleterious effects of TNF- $\alpha$ [20].

We observed high levels of TNF- $\alpha$ and its receptors in ESRD. Levels ranged widely among patients and an individual susceptibility is suspected.

Haemodialysis is known to induce release of TNF- $\alpha$ [6] with subsequent release of its receptors. The elevated TNF- $\alpha$ may reflect stimulation of circulating mononuclear cells during the haemodialysis procedure. Increased levels of soluble receptors could be a retention phenomena from the chronic renal failure per se or by an active cleavage of the soluble receptors from activated mononuclear cells which may occur during haemodialysis [7]. The elevation of TNF- $\alpha$ and its soluble receptors in our haemodialysed patients is in agreement with previous publications $[7,14,3,18]$.

The serum TNF- $\alpha$ and its soluble receptors in our study started to increase two days before the onset of acute rejection (R-2) followed by increase of serum creatinine on the day of rejection episode (R0). Renal biopsy and creatinine are the bases for starting anti-rejection therapy.

Therefore, it seems important to assess these parameters as they will offer an early diagnosis of rejection and planning for therapeutic strategy. Our findings are consistent with that of Keil [11] and Dorge [7].

During cyclosporine nephrotoxicity, our observations revealed insignificant decrease in serum levels of TNF- $\alpha$ whereas the levels of soluble inhibitory receptors were increased. Our findings were similar to the results of Dorge [7]. Possible explanations for such observations are: TNF- $\alpha$ is not affected by the decline of kidney function [7] and CSA decreases TNF- $\alpha$ release from mononuclear cells directly or indirectly by blocking interleukin 2 release from lymphocytes [9]. 
The role of TNF- $\alpha$ and its soluble receptors in the detection of allograft rejection versus CS-A nephrotoxicity was reported by Dorge et al. [7] who expressed TNF- $\alpha$ in relation to its soluble receptors. They found that the ratios TNF- $\alpha$ to SR55 and SR75 decreased during CSA nephrotoxicity and were not different during acute rejection episodes. However, in our study, we detected a highly significant increase of the ratios during rejection episodes and insignificant decrease during CSA nephrotoxicity. These ratios indicate the predominance of inhibitory soluble receptor activity over proinflamrnatory TNF- $\alpha$ activity during episodes of CS-nephrotoxicity but not during acute rejection episodes [7]. Therefore, the expression of TNF- $\alpha$ in relation to its naturally occurring inhibitors provides a better parameter to discriminate acute rejection episodes from cyclosporine nephrotoxicity and suggests a pathophysiological role of TNF- $\alpha$ in acute allograft rejection [7]. In the present study, we focused our work on transplant recipients with well functioning grafts and those with episodes of acute rejection or CSnephrotoxicity. Further studies are suggested to clarify the role of both TNF- $\alpha$ and its soluble receptors in acute tubular necrosis, intercurrent infection and during anti-rejection therapy.

\section{References}

1. Beutler B. and Cerami, A.: Cachectin: more than a tumour necrosis factor. N. Engl. J. Med. 1987; 316: 379.

2. Brockhaus M., Schoenfeld H.. Schlaeger E., Hunziker W., Lesslauer W. and Loetscher H..: Identification of two types of tumour necrosis factor receptors on human cell lines by monoclonal antibodies. Proc. Natl. Acad. Sci. USA 1990;87: 3127.

3. Brockhaus M., Bar-Khayim Y. Gurwicz S., Frensdorff A. and Haron N.: Plasma tumour necrosis factor soluble receptors in chronic renal failure. Kidney Int. 1992; 42: 663.

4. Collet-Martin S., Depoix J., Hvass $Y$. and Goldman M: Raised plasma levels of tumour necrosis factor in heart allograft rejection. Transplant. Proc. 1990; 122: 283.

5. Dembic Z., Loetscher H., Gubler and V. et al. 1990: Two human TNF receptors have similar extracellular but distinct intracellular domain sequences. Cytokine, 2:231. Quoted from Dorge et al., 1994.

6. Dinarello CA: Interleukin I and tumour necrosis factor and their naturally occurring antagonists during haemodialysis. Kidney Int. 1992; 38 [Suppl]: 68.
7. Dorge S., Lombard P., Dayer J., Koch K., Frei U. and Lonnemann G.: Plasma levels of tumour necrosis factor (TNF) and soluble TNF receptors in kidney transplant recipients. Transplantation, 1994; 58 (9): 1000.

8. Erikstein B.. Smeland E., Blomhoff H. and Wedgwood J.: independent regulation of $55 \mathrm{KDa}$ and $75 \mathrm{KDa}$ tumour necrosis factor receptors during activation of human peripheral blood B lymphocytes. Eur. J. Immunol. 1991; 21: 1033

9. Espevik T., Figari, IS, Shalaby, MR and Denis M.: Inhibition of cytokine production by cyclosporine $A$ and transforming growth factor beta. J. Exp. Med. 1987; 166: 571.

10. Gehr G., Gentz R., Brochhaus M., Loetscher H. and Lesslaue W.: Both tumour necrosis factor receptor types mediate proliferative signals in human mononuclear cell activation. $\mathrm{J}$. Immunot. 1992; 149: 911 .

11. Keil M., Pec. M., Schenn G., Grunberger T., Kramer G. Fugger R., Steininger R., Muhlbacher F., Blacke P. and Stockenhuber F.: Value of serum soluble tumour necrosis factor concent-rations in the diagnosis and prognosis of renal graft rejection. Nephrol. Dial. Transplant. 1994; 9: 815.

12. Lantz M., Gullberg U.. Nilsson E. and Olsson I.: Characterization in vitro of a human tumour necrosis factor-binding protein: a soluble form of a tumour necrosis factor receptor. $J$. Clin. Invest. 1990; 86: 1396.

13. Lonnemann G., Endres S., vander Meer J. and Mannel D.: Differences in the synthesis and kinetics of release of interleukin I $a$, interleukin $I \mathrm{~b}$ and tumour necrosis factor from human mononuclear cells. Eur. J. Immunol. 1989; 19: 1531 .

14. Maury C. and Teppo A.: Raised serum levels of cachectin / tumour necrosis factor a in renal allograft rejection. J. Exp. Med. 1987; 166: 1132.

15. Mclaughlin P., Aikawa A., Davis H., Ward R., Bakran A. Sells R., and Johnson P.: Evaluation of sequential plasma and urinary tumour necrosis factor alpha levels in renal allograft recipients. Transplantation 1991; 51 (6): 1225.

16. Nawroth P., Bamk 1., Handley D. and Cassimers J.: Tumour necrosis factor / cachectin interacts with endothelial cell receptors to induce release of interlcukin I Exp. Med., 1986; 163: 1363.

17. Nguyen DT, Eskandai MK, DeForge L.E and Remick D: Cyclosporine a modualtion of cumour necrosis factor gene expression and effects in vitro and in vivo. Immunol. 1990; 144: 3822 .

18. Noronha IL, Daiel V., Mohring K. and Opelz G.: Analysis of plasma interleukin 2 receptor (SIL-2R) and tumour necrosis factor alpha $(T N F-\alpha)$ in renal transplant patients. Clin. Transplantation 1992; 6: 277.

19. Seckinger P., Isaa S, and Dayer J.: 1989 Purification and biologic characterization of a specific tumour necrosis factor a inhibitor. J. Biol. Chem., 264: 11966. Quoted from Lambert, C.; Berthoux, P., Vindimian, M. et al, Natural serum TNF antagonists in end stage renal failure and following renal transplantation. Nephrol. Dial. Transpl. 1994; 9: 179 !.

20. Tartaglia L. and Goeddel, D.: Two TNF receptors Immunol. Today 1992; 13: 151. 